\title{
TEREBELLA MADREPORARUM.
}

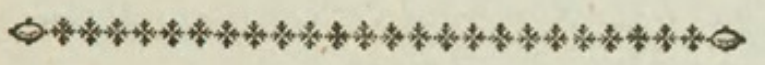

CHARACTER GENERICUS.

Corpus oblongum repens nudum, branchiis ad

latera infructum, fæpius in tubulo.

Os anterius labiatum edentulum, probofcidem clavatam exferens.

Tentacula circum os capillaria, plura, ciliata. Lin. Syft. Nat. Gmel. p. 3112.

CHARACTER SPECIFICUS, छेC.

TEREBELLA tentaculis fpiraliter fafciculatis, probofcidis difco bicorni.

TEREBELLA probofcidis difco fimplici terminali bicorni ??

$$
\text { Lin. Syft. Nat. Gmel. p. } 3114 .
$$

AEt. Angl. tom. $75 \cdot$ p. 333 . i. 11.

In opere hoc noftro jam antea notatum eft, foramina quæ in Madreporis magnis et globofis fæpius cernuntur, non a natura originem ducere, fed ab animali aliquo fedem fibi in madrepora quærente, effe terebrata. Qui de hoc plus doceri cupit, adeat . lector Actorum Anglicorum volumen feptuagefimum

$$
\text { L } 2
$$

quintum, 
quintum, in quo infigne profertur exemplum ab ingeniofo Domino Home, qui commentario fuo adjecit quicquid præterea obfervavit celeberrimus Joannes Hunterus. Et quantum colligere poffumus a figura, quam inde in tabellam noftram tranfulimus, ut melius illuftraretur res de qua quaritur; cenfemus animal in madrepora latitans, fpeciem effe Terebellæ; quæ cum femel madreporam terebraverit, manet in cavo, exinde fe, ut verifimile eft, ad libitum protrudens, prædæe fudio.

Figura prima oftendit animal e foramine exemptum. Secunda fruftum madreporæ cum cellula in qua latet Terebella. 

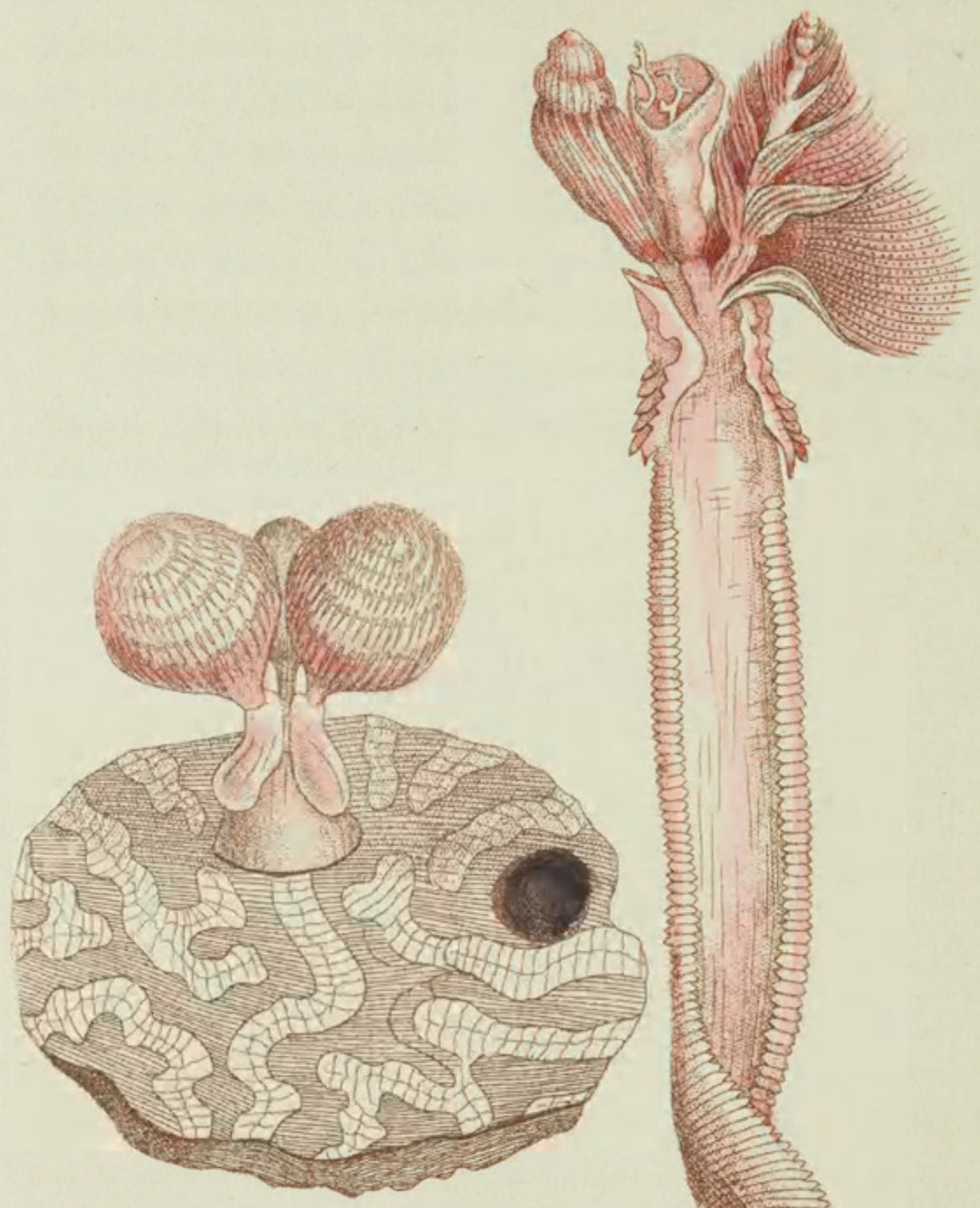
THE

\section{MADREPORE TEREBELLA。}

Q

\section{GENERIC CHARACTER.}

Body oblong, repent, naked: often inhabiting a tube.

Mouth without teeth, in fome fpecies exferting a clavated probofcis.

Tentacula feveral, capillary and ciliated; in fome fpecies fafciculated.

\section{SPECIFIC CHARACTER.}

TEREBELLA with fpirally fafciculated tentacula; the head of the probofcis fumifhed with two horns.

It has been already obferved in the courfe of the prefent work, that the foramina which frequently appear in fome of the larger globofe Madrepores, are not always owing to the natural fructure of the coral, but rather to the operation of fome other animal, which thus forms itfelf a habitation in the madrepore. Of this a curious inftance has been obferved by the ingenious $\mathrm{Mr}$. Home, whofe memoir on this fubject may be feen in the feventy-fifth volume 
volume of the Philofophical Tranfactions, accompanied by fome farther obfervations by Mr. John Hunter. From the figure there given, and which we have here copied, as an illuftration of this particular, it appears that the animal fhould be confidered as a fpecies of Terebella, which, when it has formed itfelf a hole in the madrepore, continues to refide there, and may be fuppofed to protrude itfelf occafionally from its cell in queft of prey.

Fig. I. The animal taken out of its cell.

Fig. 2. A piece of the madrepore, with the cell in which the terebella refides. 


\section{$2 \mathrm{BHL}$ Biodiversity Heritage Library}

Shaw, George. 1797. "The Madrepore Terebella, Terebella madreporarum [PI. 290]." The Naturalist's Miscellany 8(XCIV), https://doi.org/10.5962/p.310833.

View This Item Online: https://www.biodiversitylibrary.org/item/276320

DOI: https://doi.org/10.5962/p.310833

Permalink: https://www.biodiversitylibrary.org/partpdf/310833

\section{Holding Institution}

Museums Victoria

\section{Sponsored by}

Atlas of Living Australia

\section{Copyright \& Reuse}

Copyright Status: Public domain. The BHL considers that this work is no longer under copyright protection.

This document was created from content at the Biodiversity Heritage Library, the world's largest open access digital library for biodiversity literature and archives. Visit BHL at https://www.biodiversitylibrary.org. 